\title{
Determination of agricultural land suitability with a multiple-criteria decision-making method in Northwestern Turkey
}

\author{
T. Everest ${ }^{1} \cdot$ A. Sungur ${ }^{2} \cdot$ H. Özcan ${ }^{2}$
}

Received: 8 May 2020 / Revised: 24 June 2020 / Accepted: 27 July 2020 / Published online: 6 August 2020

(c) Islamic Azad University (IAU) 2020

\begin{abstract}
This study was carried out in the district of Lapseki in Çanakkale, Turkey. The suitability of land in Lapseki for agriculture was evaluated by using an analytic hierarchy process. In the study, the basic parameters were determined by using the soil map and the Shuttle Radar Topography Mission data. Land use capability classes, soil depth, erosion risk and other soil properties (limiting factors) were obtained from the soil map, while slope, elevation and aspect were obtained from the Shuttle Radar Topography Mission data. To determine the weight of the parameters in the analytic hierarchy process, the opinions of the public institutions and experts were obtained. The obtained data were analyzed with the analytic hierarchy process and mapped with geographic information systems techniques, and a land suitability map was generated. The agricultural land suitability map demonstrated that $2.95 \%$ (2557 ha) of the lands in the study area were highly suitable; $10.37 \%$ (8989 ha) were moderately suitable; $53.47 \%$ (46,336 ha) were marginally suitable; and $33.21 \%$ (28,775 ha) were not suitable for agricultural use. The data from the agricultural land suitability map were compared with the Coordination of Information on the Environment 2012 data. As a result of comparison, 14.12\% (361 ha) of highly suitable lands for agriculture and $2.25 \%$ (202 ha) of moderate suitable lands for agriculture are urbanized. It was seen that $45.71 \%$ (24,837 ha) of the lands that are marginally suitable for agriculture and $18.76 \%$ (5397 ha) of the not suitable lands had current land use for agriculture.
\end{abstract}

Keywords Analytic hierarchy process $\cdot$ Environmental monitoring $\cdot$ Geographic information systems $\cdot$ Lapseki $\cdot$ Suitable site selection

\section{Introduction}

The world population is constantly increasing, from 1.6 billion in the early 1900s to 7.6 billion nowadays (PRB 2018). With the increase in population, people have started to use lands more and more for their basic needs. So, agricultural, pasture and forest lands are constantly degraded. For this reason, land use types are being changed due to misuse of land.

The decrease in agricultural lands in semiarid climatic conditions puts increased pressure on these lands. Due to

Editorial responsibility: Samareh Mirkia.

T. Everest

timucineverest@comu.edu.tr

1 Lapseki Vocational School, Çanakkale Onsekiz Mart University, 17800 Çanakkale, Turkey

2 Soil Science and Plant Nutrition Department, Çanakkale Onsekiz Mart University, 17020 Çanakkale, Turkey this pressure on land resources, land degradation can occur (Elaalem et al. 2011; Feizizadeh and Blaschke 2013).

Land consists of physical environments such as soil, relief, climate, vegetation and hydrology that have direct effect on land use potential (FAO 1977). It is essential to use lands according to their potential and capabilities to obtain optimal productivity (Everest et al. 2011). Land suitability analysis is a key practice for the sustainable use of land (Cengiz et al. 2013). Land suitability studies started at the beginning of the twentieth century with hand-drawn overlay analysis (Steinitz 1976; Collins et al. 2001; Malczewski 2004). The concept of land suitability is defined as the adaptation of the land for a specific land use (Driessen and Konijn 1992). Land use suitability analysis is characterized by the process of selecting the most suitable area for a type of use (forest, agriculture, recreation, etc.) based on various degrees (Cengiz and Akbulak 2009; Akbulak 2010; Al-Shalabi et al. 2006; Akıncı et al. 2013). Appropriate algorithm selection is necessary for evaluating land suitability and future land management practices (Zhang et al. 2015). Land 
use suitability analysis evaluates the suitability of land and considers the environmental and socioeconomic processes as well (Malckzewski and Ogryczak 1995; Bojorquez-Tapia et al. 2000; Cengiz and Akbulak 2009).

There are numerous multiple-criteria decision-making methods such as analytic hierarchy process (AHP) (Saaty 1980), Electre (Tzeng and Huang 2011), Topsis (Chen 2000), Promethee (Brans and Vincke 1985), Grey theory (Özcan et al. 2011), etc. AHP is one of the multiple-criteria decision-making methods used for the assessment and analysis of land use suitability. AHP involves multiple selections based on the importance and weight of the parameters relative to each other within a hierarchical system (Saaty 1980). It is useful when it is difficult to specify the certain relationship between large numbers of criteria (Chen et al. 2010). AHP is a system which uses a hierarchical approach with multiple criteria. The system is based on scoring and a pairwise comparison matrix to determine the relative importance of a factor to other factors on a level (Akbulak 2010).

The use of the AHP method for determination of land suitability has gained popularity recently. There are different studies discussing the uses of AHP in the literature. Among them, there are studies on the land use suitability for different crops (Mustafa et al. 2011), suitability for agricultural land use (Feizizadeh and Blaschke 2013; Akınc1 et al. 2013; Zolekar and Bhagat 2015; Chandio et al. 2014), suitability for different land use types (agricultural, pasture and forest lands) (Cengiz et al. 2013; Cengiz and Akbulak 2009; Akbulak 2010), land suitability for rice (Maddahi et al. 2017), forage legumes (Özyazıcı et al. 2016), citrus cultivation (Mokarram and Mirsoleimani 2018), livestock development planning (Qiu et al. 2017), selection of suitable regions for urban services (Parry et al. 2018) and the determination of energy production areas (Asakereh et al. 2017; Al-Yahyai et al. 2012; Hashemizadeh et al. 2019).

Optimal use of natural resources is very important for the environmental sciences. Land degradation is a major threat to natural resources. Misuse and inappropriate management of land are the major reasons for degradation. Site selection is an important component of sustainable land use management strategies. Reduction and degradation of land necessitates sustainable agricultural practices. One of the best ways to prevent soil degradation is land suitability analysis. Many environmental problems can occur when the land is not used in accordance with its capabilities and properties. Land suitability analysis proposes the optimal land use opportunities.

Marmara is the most populated region in Turkey. Lapseki district is one of the most important agricultural areas in the Marmara region. Besides its agricultural potential, it has special microclimatic conditions and the highest quality peaches and cherries in Turkey are grown in this area. Peach and cherry from Lapseki are branded due to quality characteristics, and almost all products are exported to Europe mainly. This is the main reason to study Lapseki. The main purpose of this study is to determine land suitability by taking into consideration land degradation and sustainable agricultural principles in the region with high agricultural potential. In the literature, there are a few studies about land suitability and land use efficiency analysis for special locations such as Lapseki district. The combined technique of geographic information systems (GIS) and AHP was used in this study for determination of suitable lands for agriculture. In this study, the aim was to determine agricultural land suitability by using the AHP method, to compare with current land use in 2019 and to produce real data for land owners and decision makers about how to evaluate the land of Lapseki district in Çanakkale, northwestern (NW) Turkey.

\section{Material and method}

\section{Study area}

This study was performed in the district of Lapseki, in the province of Çanakkale (NW Turkey). Lapseki is located between $40^{\circ} 24^{\prime} 00^{\prime \prime}-40^{\circ} 12^{\prime} 00^{\prime \prime}$ latitude north, $26^{\circ} 30^{\prime}$ $00^{\prime \prime}-26^{\circ} 54^{\prime} 00^{\prime \prime}$ longitudes east (Fig. 1). The study area covers approximately $867 \mathrm{~km}^{2}$. The total population of Lapseki is 26,370. In Lapseki, 12,537 people live in urban areas, while 13,833 live in rural areas (ADNKS 2017).

Lapseki is located in the transition area between the Marmara and Aegean regions. Accordingly, it is also in the transition climate zone of these two regions. In the study area, according to Turkish State Meteorological Service statistical data, summers are hot and dry, while winters are cool and rainy and precipitation usually falls as rain. It is snowy for a short time in the winter. The coldest month in the region is January with an average of $6{ }^{\circ} \mathrm{C}$, whereas the warmest month is July with an average of $25^{\circ} \mathrm{C}$. The rainiest months are November, December, March and April. The average precipitation is about $616.3 \mathrm{~mm}_{\text {year }}{ }^{-1}$. The months with the lowest rainfall are July and August. Based on the climate classification of Thornthwaite (1948), the climate in the basin is $\mathrm{C}^{\prime}, \mathrm{B}^{\prime} 2, \mathrm{~s} 2, \mathrm{~b}^{\prime} 3$, semiarid, less humid, mesothermal, with large winter water surplus and summer evaporation rate of $53 \%$.

The elevation of the lands in Lapseki varies between 0 and $763 \mathrm{~m}$. The geology in the area varies from Quaternary to Cretaceous. Alluvium is the youngest unit which formed in the Quaternary. The volcanic rocks with Eocene age outcrop in the southeast of the region and cover a large part of the study area. The northeast of the study area is dominated by granodiorites and gneisses of Oligocene age. In the north, there are ophiolitic mélanges formed in the upper Cretaceous. The other geological facies are sedimentary clastic rocks with Pliocene and Miocene ages (MTA 


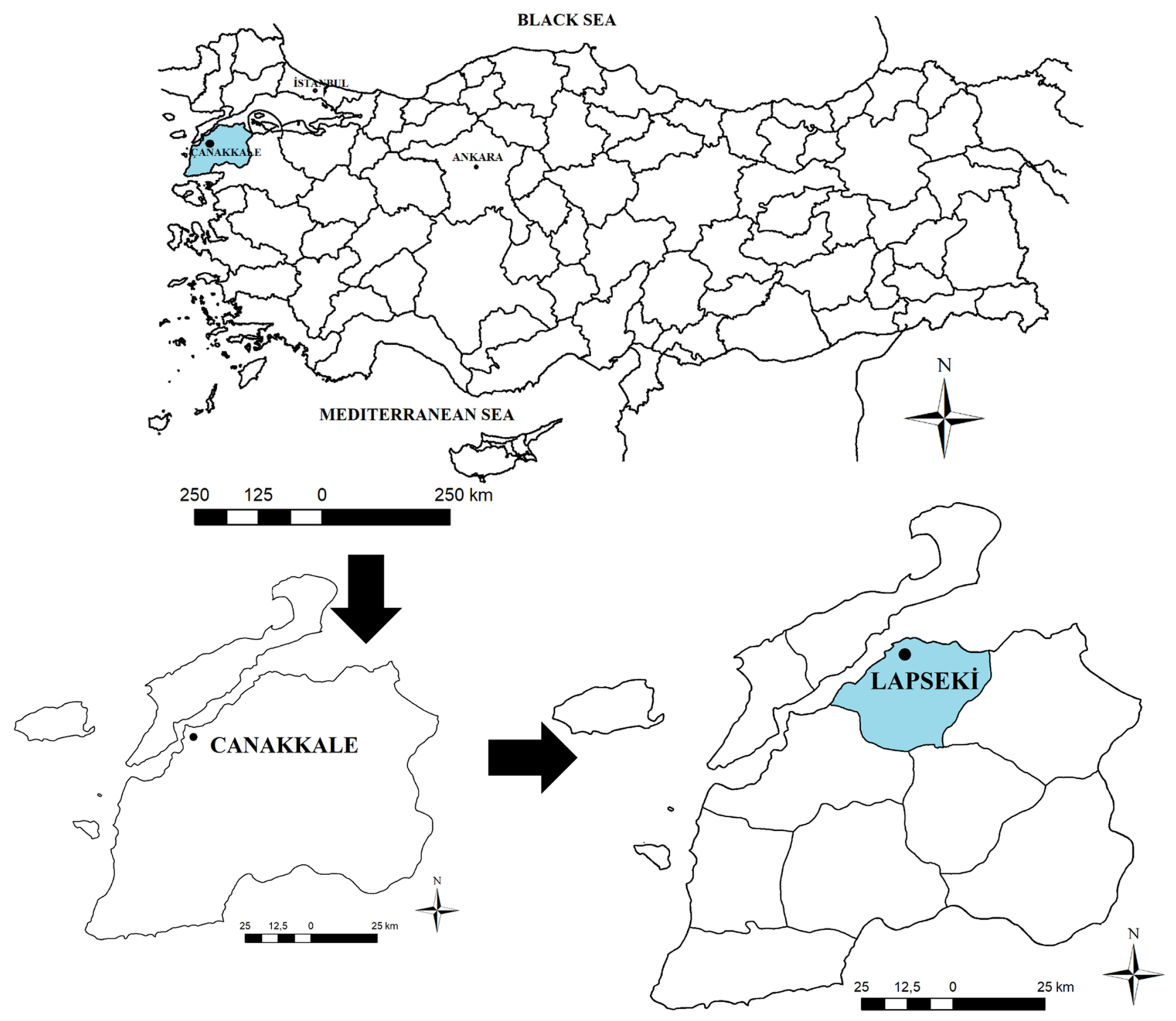

Fig. 1 Study area

2018). The largest soil groups in the area are alluvial, colluvial, red brown forest, brown forest, non-calcareous brown forest, non-calcareous brown and vertisols (KHGM 1999; Özcan et al. 2018).

Lapseki has important agricultural potential. The study area is famous for fruit production and most of these fruits are exported to Europe. Peach and cherry are very common, and apple, apricot, plum and pear are also planted in large area. Besides these land use types, many field crops and vegetables are also cultivated in the area.

\section{Land suitability analyses}

In order to determine land suitability for agriculture, two different cartographic materials were used. The first one was the soil map with $1 / 100,000$ scale which was obtained from the provincial inventory report published by the General Directorate of Rural Services (KHGM 1999). Land use capability classes (LUCC), depth, erosion hazards, and other soil properties (rocky, stony, drainage, salinity) were obtained from the soil map. The second one was 30-m spatial resolution of Shuttle Radar Topography Mission (SRTM) data which were downloaded from the NASA website. The parameters of elevation, slope and aspect were generated from the SRTM data.

\section{Soil properties}

Many land characteristics related to soil were used for land suitability analyses. These land characteristics are LUCC, 
soil depth, erosion hazard and other soil properties (limiting factors) (Fig. 2).

\section{LUCC}

Land use capability classification is a fundamental argument which shows the agricultural production suitability of lands. In other words, land use capability classification allows easier comprehension of a land survey (Everest 2017). LUCC considers land characteristics and sub-parameters such as climate, soil, topography and drainage properties. It further evaluates and classifies the suitability of lands for all types of cultivated plants. In the LUCC classification, there are two orders and eight classes. These two orders are described as suitable for cultivation order and not suitable for cultivation order. There are eight classes ranging from I to VIII in LUCC. The first four classes are capable of producing adapted plants under good management. The last four classes are not suitable for agricultural practices. The number of cultivated plants and the suitability of the land characteristics decrease from class I to class VIII. While the lands in class I and II are suitable for almost all types of cultivated plant growing, the suitability for cultivated plant growing decreases from class III. The lands in class V are not suitable for cultivation in their current situation. They can be converted to suitable lands like (class I, II or III) after cultural and chemical improvements. The lands in classes VI, VII and VIII are not suitable for cultivation due to slope and soil shallowness problems. The lands in class VI should be used for pasture and forest, whereas the lands in class VII should be under forest cover (FAO 1989; KHGM 1999; Everest et al. 2011). In the study area, class I lands covers $1.93 \%$, class II $1.63 \%$, class III 1.96 , class IV $9.35 \%$, class VI $17.08 \%$, class VII $67.87 \%$ and class VIII $0.15 \%$ of the total area (Table 1).

\section{Depth}

Soil depth is one of the most important factors for plants to reach water and nutrients. It affects the healthy growth and propagation of the roots. The plants with healthy root development can easily access nutrients and water.
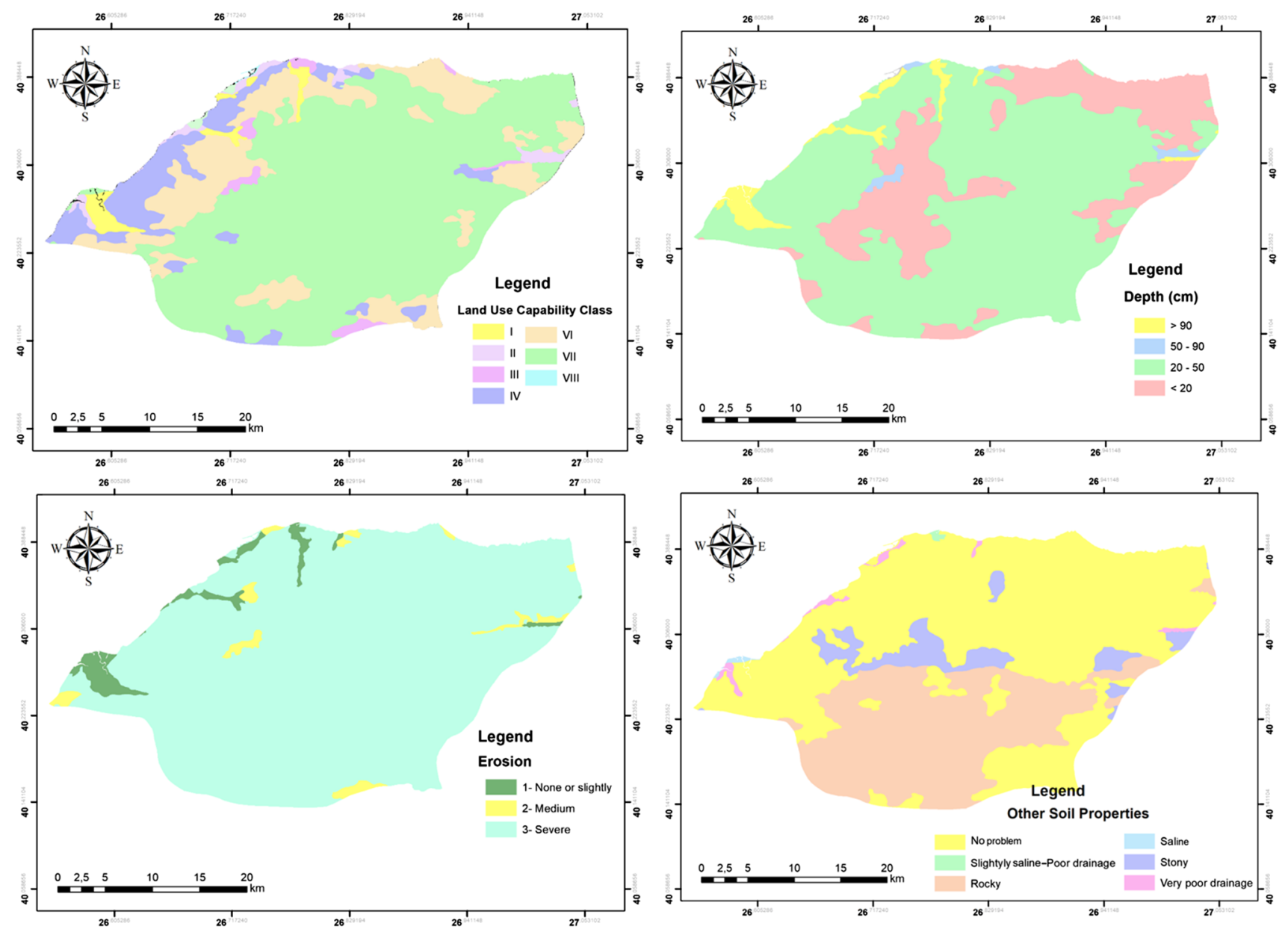

Fig. 2 Soil properties (LUCC, depth, erosion hazard and other soil properties) 
Table 1 Main criteria and sub-criteria belongs to soil properties

\begin{tabular}{llrr}
\hline Parameter & Classification & Area (ha) & $\%$ \\
\hline Soil properties & & & \\
LUCC & I & 1676.12 & 1.93 \\
& II & 1416.00 & 1.63 \\
& III & 1703.53 & 1.96 \\
& IV & 8101.47 & 9.35 \\
& VI & $14,802.39$ & 17.08 \\
& VII & $58,829.88$ & 67.87 \\
& VIII & 127.61 & 0.15 \\
& Deep & 2768.21 & 3.20 \\
Depth & Medium-deep & 865.32 & 1.00 \\
& Shallow & $56,361.68$ & 65.14 \\
& Very shallow & $26,532.79$ & 30.66 \\
Erosion hazard & None or slightly & 2768.15 & 3.20 \\
& Medium & 1658.96 & 1.91 \\
& Severe & $82,101.65$ & 94.89 \\
& Rocky & $29,988.11$ & 34.65 \\
Other soil properties & 5264.95 & 6.08 \\
& Stony & 336.51 & 0.39 \\
& Very poor drainage & 92.17 & 0.10 \\
& Slightly saline-poor drain- & & \\
& age & 118.65 & 0.13 \\
& Saline & $50,729.00$ & 58.65 \\
\hline & No problem & &
\end{tabular}

Soil depth is a significant parameter which changes the potential root volume. Root volume affects hydrological events and water exchange amounts in plants (Meyer et al. 2007). Soil depth is directly related to topographic conditions (Gabet and Mudd 2009). In steep and sloping areas, the susceptibility to erosion increases, while soil depth decreases. Lands classified for depth in the study area were: $3.20 \%$ deep; $1 \%$ medium-deep; $65.14 \%$ very shallow and $30.66 \%$ shallow (Table 1 ).

\section{Erosion hazard}

Erosion is correlated with many factors such as slope, land cover, land use and climatic conditions. The soil reduction due to erosion adversely affects the efficiency of the soil (Montgomery 2007). Erosion causes soil loss, degradation of soil structure, decreases in organic matter, plant nutrients and soil depth (Pimentel et al. 1995). Soil depth rapidly decreases when the intensity of erosion increases. Erosion can be very intense in some areas, so soil completely reduces and the bedrock appears (Altınbaş 2006). There are no or slight erosion threats in $3.20 \%$ of total lands, with medium erosion threat in $1.91 \%$ of total land and severe erosion threat $94.89 \%$ of the study area (Table 1).

\section{Other soil properties (limiting factors)}

Other soil properties in the study area are rocky, stony, drainage and salinity conditions. Bedrock appears with the effect of erosion, soil shallowness and lithological structure. These conditions affect soil management practices (Dinç and Şenol 1997). Rocky conditions reduce crop production and variability. It is a very restrictive factor, particularly for grain cultivation (Özcan 2015). In the study area, $34.65 \%$ of the land has rocky conditions (Table 1). Another restrictive soil property, followed by rocky conditions, is stoniness. The gravel and stone-sized materials on the soil surface which originate from the parent material impact soil tillage practices and the variety of crops negatively (Dinç and Şenol 1997). Of the study area, $6.08 \%$ has a stoniness problem (Table 1). Drainage and salinity problems are particularly present in areas where the level of groundwater is very close to the surface. The area of interaction with the sea water also has drainage and salinity problems. This local problem occurs in $0.23 \%$ of the study area (Table 1 ).

\section{Topographic parameters}

Topographic parameters were examined in three categories. These are slope, elevation and aspect. Slope and aspect were derived from the SRTM data with $30 \mathrm{~m}$ spatial resolution. There are different algorithms for calculating slope from DEM, and these algorithms are classified under two headings (1-averaging methods and 2-maximum slope methods). Averaging methods compute the slope from four (Zevenbergen and Thorne 1987) or eight (Horn 1981) neighbor cells. On the other hand, maximum slope methods compute the slope by focusing on the center pixel and one of its neighboring pixels which maximize altitude variation (Travis et al. 1975; Burrough and McDonnell 1998; Dunn and Hickey 1998; Ashraf et al. 2012). Horn (1981) is a widely used slope calculation method. In this method, the least squares are formed on a plane for the elevation of the eight cells neighboring the target cell. The result of the calculation presents the slope and aspect on the cell scale (Goulden et al. 2016). In this study, the averaging method with eight neighbor cells presented by Horn (1981) was used to compute slope and aspect. ArcGIS software uses Horn's methodology for calculating slope and aspect as default software standard (Ashraf et al. 2012). The elevation map was generated by using five different classes of DEM (Fig. 3).

\section{Slope}

Slope is an important factor for agriculture. Slope degree has a direct effect on soil depth, susceptibility to erosion, soil tillage, use of agricultural machines, irrigation, plant adaptation, etc. The steepness, length and sharpness of the slope 

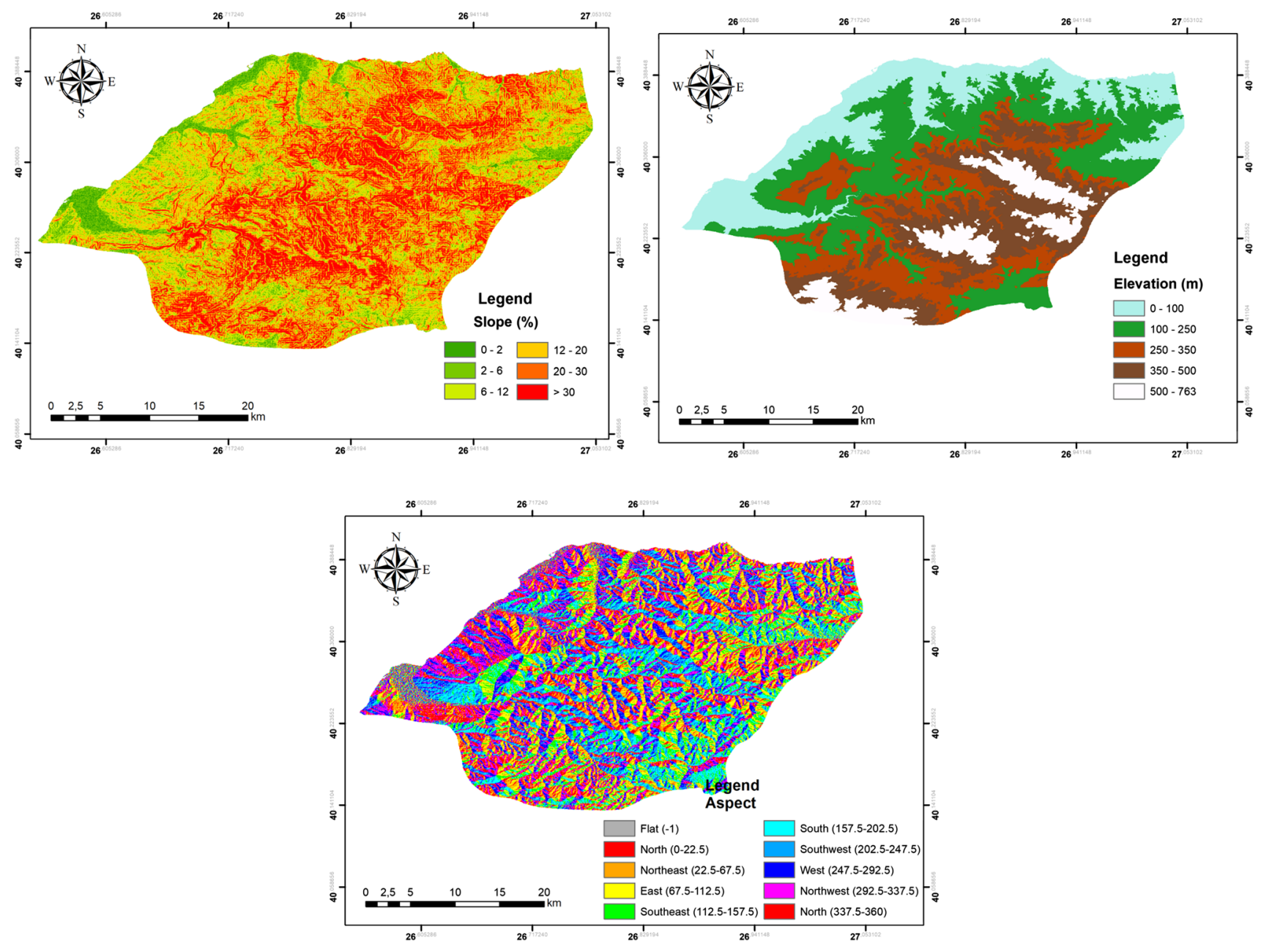

Fig. 3 Topographic parameters (slope, elevation and aspect)

directly affect the soil and water loss in an area. The effects of slope on soil erosion were reported by many researchers (Selby 1976; Kinnell 2000; Parlak 2012). The effect of slope on soil formation is very effective. If the slope is different and the climatic conditions do not change, different soils can form on the same parent material (WRB 2014). Approximately $42 \%$ of the study area has steep and very steep slopes (Table 2).

\section{Elevation}

Elevation is one of the fundamental elements for agricultural production and diversity. Elevation increases from the coastal regions to the interior. The difference in elevation indicates that winter months are longer and summer months are shorter and cooler (Kapluhan 2013). Physiological and morphological differences can occur in the same plant species due to changing climatic conditions with elevation (Özkan and Kantarci 2008). Therefore, one of the plants in the same species matures in a shorter period than the other
Table 2 Main criteria and sub-criteria belongs to topographic parameters

\begin{tabular}{llrr}
\hline Parameter & Classification & Area (ha) & $\%$ \\
\hline Topographic parameters & & \\
Elevation (m) & $0-100$ & $17,091.61$ & 20.90 \\
& $100-250$ & $25,241.36$ & 30.87 \\
& $250-350$ & $16,860.42$ & 20.63 \\
& $350-500$ & $15,255.53$ & 18.65 \\
& $500-763$ & 7310.45 & 8.95 \\
Slope (\%) & $0-2$ & $20,132.63$ & 2.46 \\
& $2-6$ & $79,962.29$ & 9.78 \\
& $6-12$ & $163,212.34$ & 19.96 \\
& $12-20$ & $214,522.28$ & 26.24 \\
& $20-30$ & $187,314.45$ & 22.91 \\
Aspect & $>30$ & $152,449.92$ & 18.65 \\
& North & 8954.92 & 10.95 \\
& West, east & $21,675.39$ & 26.51 \\
& South, southeast, southwest & $33,214.53$ & 40.62 \\
& Northwest, northeast & $17,914.55$ & 21.91 \\
\hline
\end{tabular}


plant. Vegetation period has a direct effect on harvesting time and profitability in crop production. The lowest elevation in the study area is $0 \mathrm{~m}$, and the highest elevation is $763 \mathrm{~m}$ (Table 2).

\section{Aspect}

Aspect is one of major elements in crop production. Aspect causes ecosystem changes. It is associated with plant variety, distribution of plant species, vegetation period and crop yield. Plants need sunlight, so they can perform their physical and metabolic activities. When plants benefit from sunlight, they germinate, develop their organs and give fruit (Bale et al. 1998; Yimer et al. 2006). The data based on the aspect in the study area are presented in Table 2.

\section{Cartographic materials and software}

Soil maps and topographic layers were used for land suitability analysis in the study. LUCC, soil depth, erosion hazard and other soil properties were generated from the soil map. The DEM map was generated from SRTM data. Elevation, slope and aspect maps were created from the DEM map. Coordination of Information on the Environment (CORINE) 2012-year land cover data were used for the determination and comparison of the land uses. The CORINE land cover project identifies land use/land cover changes by using satellite images and GIS techniques in line with EU standards. These data are updated every 10 years (CLC 2012). The pairwise comparison matrix was calculated by using Microsoft Excel. ArcGIS 10.3 was used to generate the maps and to carry out spatial and overlay analysis.

\section{Analytical hierarchy process (AHP)}

AHP is a multiple-criteria decision-making method (Saaty 1980). AHP allows for a systematic and logical evaluation of group decisions. It enables the decision maker to identify the relationship between the aims, criteria, sub-criteria and alternatives of a complex problem by modeling in a hierarchy. It further leads to correct and logical results (Ozdemir and Saaty 2006; Dezert et al. 2010).

(i) The first step in the AHP method is structuring the hierarchical model. The hierarchical process involves defining the problem from top to bottom, determining criteria and sub-criteria and creating alternatives (Saaty 1980).

(ii) The second step is generating the decision matrix and performing pairwise comparisons. Here, a factor in a level is compared relatively to another factor at a higher level in the hierarchy. The definitions used in the comparison are made based on the criteria given in Table 3 . The values of the mapping units which will be used for land suitability are calculated by using weights that are assigned to criteria and
Table 3 AHP evaluation scale (Saaty 1980)

\begin{tabular}{ll}
\hline Intensity of importance & Definition \\
\hline 1 & Equal importance \\
3 & Moderate importance \\
5 & Essential or strong importance \\
7 & Demonstrated importance \\
9 & Absolute importance \\
$2-4-6-8$ & Intermediate values \\
\hline
\end{tabular}

sub-criteria. The process of calculating the weights for the criteria is as follows (Mohammadizadeh et al. 2016):

(a) To form a $(n \times n)$ pairwise comparison matrix for multiple factors. It is proposed that $a i j=$ the selected factor (factor $i$ to factor $j$ ). Then, it assumed that $a i j=1 / a i j$.

(b) Then, the matrix values are normalized for this calculation; the sum of each column is calculated. Then, each binary comparison matrix element is divided by the total value of the column in which it is located. With this calculation, the normalized pairwise comparison matrix values are obtained (Table 4).

(c) The arithmetic mean values are calculated for each row that belongs to the normalized pairwise comparison matrix values (Table 4). The obtained mean values present an estimate of relative priorities for the compared elements.

(iii) In the final step, the consistency ratio is checked. For this, eigenvectors and the maximum eigenvalue of each matrix are calculated. Then, the consistency index is tested with the formula given below.

$$
\mathrm{CI}=\frac{\lambda_{\max }-n}{n-1}
$$

where $\lambda_{\max }$ indicates the eigenvalue of the pairwise comparison matrix.

Finally, the consistency of the pairwise comparison matrix is tested. For this, the RI value in Table 5 is used. $\mathrm{CR}$ is calculated by the formula given below.

$\mathrm{CR}=\frac{\mathrm{CI}}{\mathrm{RI}}$

where RI is the random consistency index. RI values are given in Table 5.

To be valid, its consistency rate should be $0.10(10 \%)$ or less. If the obtained rate is greater than 0.10 , it is necessary to generate the pairwise comparison matrix again (Saaty 1980). Table 4 presents the weight values of seven parameters selected for land suitability. 
Table 4 Pairwise comparison matrix and eigenvector values

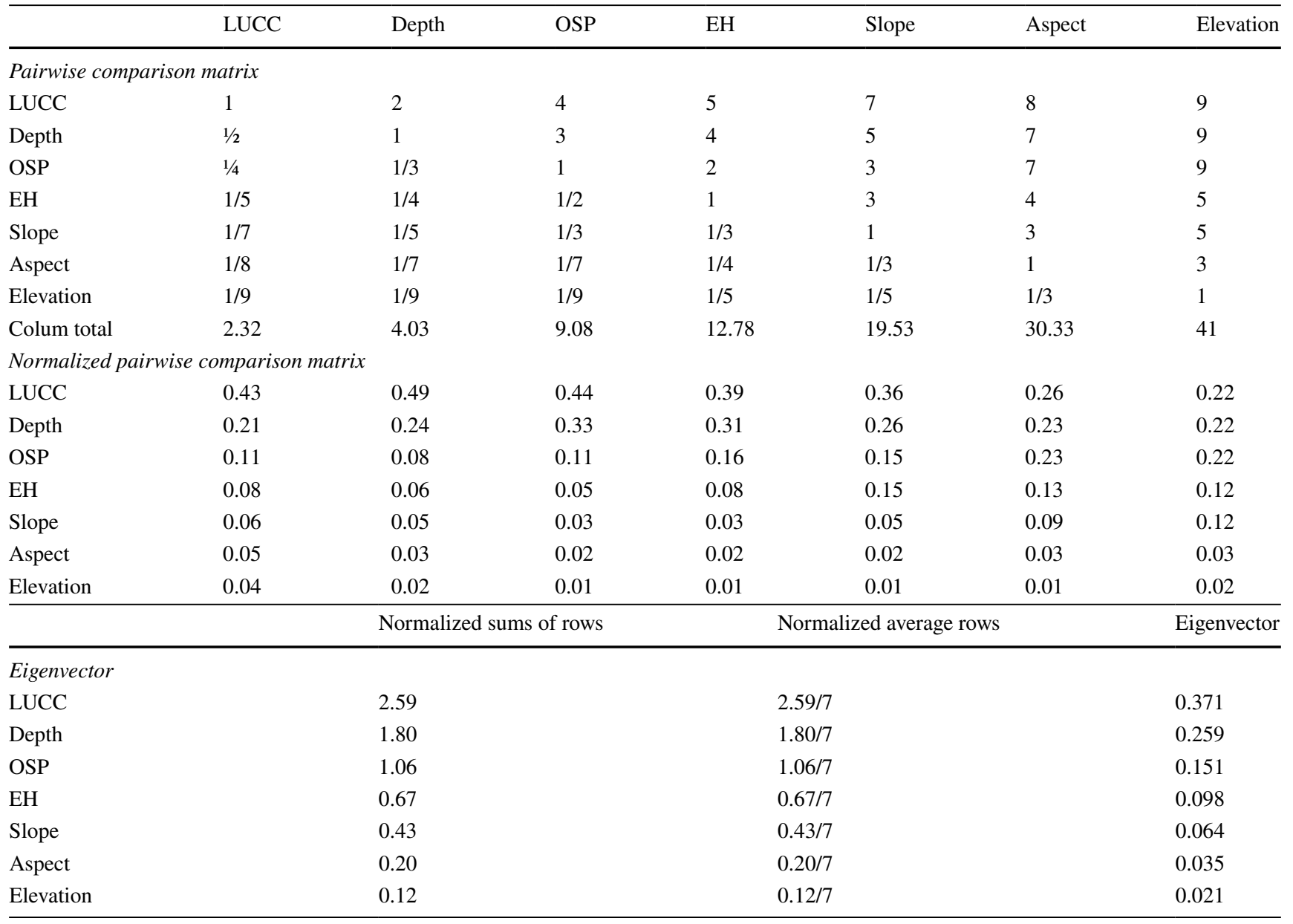

$\lambda=7.73, n=7, \mathrm{CI}($ consistency index $)=0.121, \mathrm{RI}($ random index $)=1.32, \mathrm{CR}=0.091$

Table 5 Random index (RI) values

\begin{tabular}{|c|c|c|c|c|c|c|c|c|c|c|}
\hline $\bar{N}$ & 1 & 2 & 3 & 4 & 5 & 6 & $7^{\mathrm{a}}$ & 8 & 9 & 10 \\
\hline & 0.00 & 0.00 & 0.58 & 0.90 & 1.12 & 1.00 & 1.32 & 1.41 & 1.45 & 1.49 \\
\hline
\end{tabular}

${ }^{\text {a }}$ The RI value for 7 criteria is 1.32

\section{Method}

The workflow diagram for the study is presented in Fig. 4. Initially, the border of the study area was drawn by using 1/25,000 scale topographic map. All cartographic materials were extracted by using this border. Available cartographic materials were evaluated in two main headings of soil properties and topographic parameters. Afterward, the main criteria were determined to perform AHP analysis according to the methodology. These were LUCC, depth, erosion hazard, other soil properties for soil parameters and slope, elevation and aspect for topographic parameters. After this stage, the main criteria were created and then the pairwise comparison matrix was determined (Table 4). For this purpose, opinions of many different authorities were taken. The opinions of the relevant stakeholders, public institutions and experts were collected to generate matrix values. The obtained opinions were used to score binary comparisons. After performing pairwise comparisons, the consistency ratio was checked. The consistency ratio of the study was calculated as 0.091 , which indicates that the decision matrix was consistent (Saaty 1980). After determining the main criteria and calculating the pairwise comparison matrix values, the sub-criteria were evaluated. When scoring in this study, appropriate conditions for growing the plants were compared according to the sub-criteria (Tables 6,7 ). The scoring process for each parameter is presented in detail below. 
Fig. 4 Flow diagram of the study

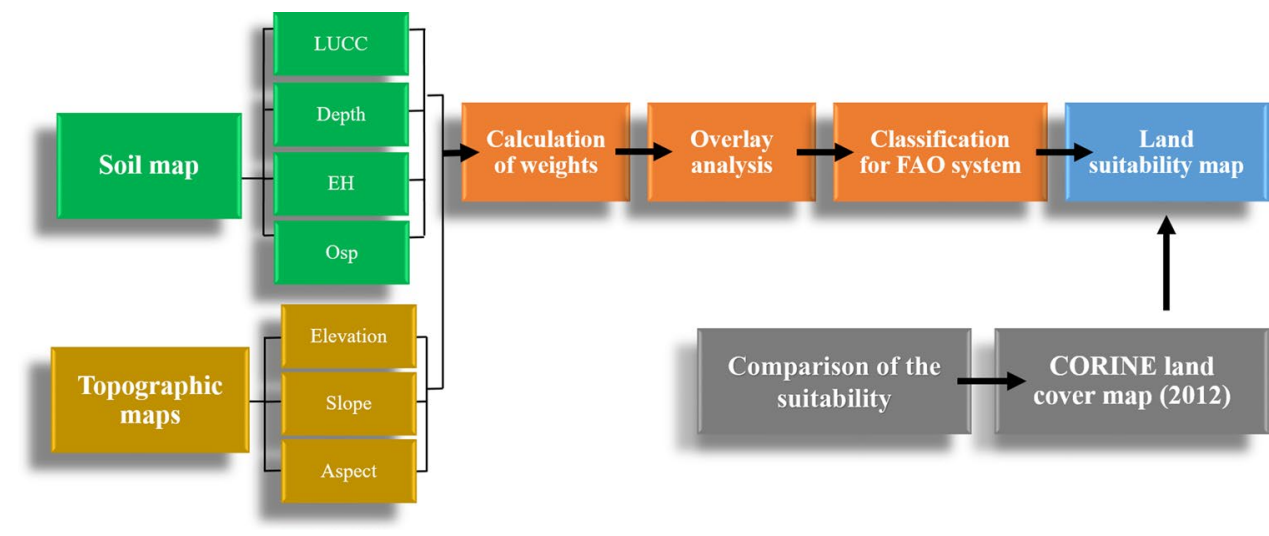

Table 6 Scores and weights of soil properties

\begin{tabular}{|c|c|c|}
\hline Main criteria & Sub-criteria & Score \\
\hline \multicolumn{3}{|l|}{ Soil properties } \\
\hline \multirow[t]{8}{*}{ LUCC $($ weight $=0.371)$} & I & 10 \\
\hline & II & 9 \\
\hline & III & 7 \\
\hline & IV & 5 \\
\hline & $\mathrm{V}$ & 4 \\
\hline & VI & 3 \\
\hline & VII & 2 \\
\hline & VIII & 1 \\
\hline \multirow[t]{6}{*}{ Depth $(\mathrm{cm})($ weight $=0.259)$} & $120+$ & 10 \\
\hline & $90-120$ & 8 \\
\hline & $60-90$ & 6 \\
\hline & $40-60$ & 4 \\
\hline & $20-40$ & 2 \\
\hline & $<20$ & 1 \\
\hline \multirow[t]{6}{*}{ Other soil properties $($ weight $=0.151)$} & No problem & 10 \\
\hline & Stony & 8 \\
\hline & Slightly saline & 6 \\
\hline & Rocky & 3 \\
\hline & Saline & 2 \\
\hline & Very poor drainage & 2 \\
\hline \multirow[t]{3}{*}{ Erosion hazard $($ weight $=0.098)$} & None or slightly & 10 \\
\hline & Medium & 7 \\
\hline & Severe & 3 \\
\hline
\end{tabular}

In scoring the LUCC data, the study assigned 10 points to the lands in class I as they have no or few slightly restrictive factors. It assigned 9 points to the lands in class II as their use is limited by a few factors. Class III lands are restricted by more factors than class II lands, so these lands were assigned 7 points. The lands in class IV were assigned 5 because they have more restricted factors than class III and due to product pattern restriction. Class V lands were assigned 4 points because plants cannot be grown normally and limited species can be grown in these lands. The lands in
Table 7 Scores and weights of topographic parameters

\begin{tabular}{llr}
\hline Main criteria & Sub-criteria & Score \\
\hline Topographic parameters & & \\
Slope (\%) (weight =0.064) & $0-2$ & 10 \\
& $2-6$ & 8 \\
& $6-12$ & 6 \\
& $12-20$ & 4 \\
& $20-30$ & 2 \\
Aspect $($ weight $=0.035)$ & $>30$ & 1 \\
& Flat & 10 \\
& S-SW-W & 9 \\
& SE-E & 8 \\
Elevation $(m)($ weight $=0.021)$ & NW & 7 \\
& NE & 6 \\
& N 100 & 5 \\
& $100-250$ & 10 \\
& $250-350$ & 9 \\
& $350-500$ & 7 \\
& $500-763$ & 5 \\
\hline
\end{tabular}

class VI were assigned 3 points since they were limited by a number of factors and problems. The study assigned 2 points to the lands in class VII due to too many limiting factors for plant growth and 1 point to the lands in the class VIII as the adverse factors in these lands cannot be prevented.

Soil depth is directly linked to the root development of a plant. It is important for water and nutrient transfer. In scoring soil depth, lands with a depth of more than $120 \mathrm{~cm}$ were assigned 10 points as they are suitable for all kinds of root systems. The study assigned 8 points to lands with a soil depth of $90-120 \mathrm{~cm}$ due to the presence of slight problems regarding their depth and 6 points to the lands with a depth of $60-90 \mathrm{~cm}$ as they fail to meet the depth needs for some plants. The lands with a depth of $40-60 \mathrm{~cm}$ and of $20-40 \mathrm{~cm}$ were, respectively, assigned 4 and 2 points since they have critical depth problems, restricting plant growth. The lands 
with a depth of less than $20 \mathrm{~cm}$ were assigned 1 point as they are very shallow.

The parameters of rocky, stony, drainage and salinity conditions adversely affect crop production. In scoring other soil properties, the lands with no problem were assigned 10 points. The lands with stony conditions were assigned 8 points; slightly saline lands were assigned 6 points as they are not suitable for growing many cultivated plants; rocky lands were assigned 3 points because of lack of soil cultivation and effective soil depth. The lands with salinity and very poor drainage were assigned 2 points due to their very restrictive use for agricultural purposes.

As a result of erosion, fertile soils are lost and this affects agricultural production because soil depth decreases. To score erosion hazard, the lands with no erosion threat and erosion threat considered as "none" were assigned 10 points. The lands with medium erosion hazard and with severe erosion hazard were, respectively, assigned 7 and 3 points.

Slope is a factor that affects many parameters such as soil cultivation, infiltration, water holding capacity, and susceptibility to erosion. For slope scoring, the lands with a slope of $0-2 \%$ were assigned 10 points; those with a slope of $6-12 \%$ were assigned 6 points as they are sloped lands. The lands with a slope of $12-20 \%$ were assigned 4 points as they are steep, and those with a slope of $20-30 \%$ were assigned 2 points as they are too steep. The lands with a slope of $30 \%$ were assigned 1 point as they are extremely steep.

The average temperature values decrease by about $0.6{ }^{\circ} \mathrm{C}$ for every $100 \mathrm{~m}$. The differences in temperature with elevation were considered in scoring. Accordingly, the study assigned 10 points to the lands with an elevation of $0-100 \mathrm{~m}$, 9 points to those with an elevation of 100-250 m, 8 points to those with an elevation of $250-350 \mathrm{~m}, 7$ points to those with an elevation of $350-500 \mathrm{~m}$ and 5 points to those with an elevation of 500-763 m.

The aspect ratio was scored according to the daylight availability in the region. Accordingly, it assigned 10 points to flat lands, 9 points to lands with $\mathrm{S}, \mathrm{SW}, \mathrm{W}$ aspects, 8 points to SE, E lands, 7 points to $\mathrm{NW}$ lands, 6 points to $\mathrm{NE}$ lands and 5 points to $\mathrm{N}$ lands.

\section{Calculation of agricultural land suitability}

After forming the matrix and scoring the sub-categories, suitability analysis was performed. For this purpose, the feature data obtained from the soil map were converted into raster format. The DEM maps were already in raster format, so they were directly transferred into the software. A model was created in the model builder on ArcGIS to perform overlay analysis. The raster maps and resulting scores were imported into the model. By combining the suitability and weighted values of the criteria in GIS, the suitability values for each pixel were calculated. Agricultural land suitability analysis was calculated with the equation given below (Zhang et al. 2015).

$S=\sum_{i=1}^{n}(W i \cdot X i)$

In this formulation, $S$ is total land suitability score; $W i$ is the weighted value of the land suitability criteria; for the subcriteria score of $X i i$ is land suitability criteria; and $n$ is the total number of land suitability criteria.

The final land suitability map was created by means of weighted overlay analysis. The resulting map was reclassified for FAO (1977) based on the suitability analyses. The final suitability map was classified into four classes. In this classification, $\mathrm{S} 1$ indicates land which is highly suitable for agriculture with no limiting factors, S2 indicates land which is moderately suitable for agriculture with some limiting factors, S3 indicates land which is marginally suitable for agriculture with severe limiting factors, and $\mathrm{N}$ indicates land which is not suitable for agriculture.

\section{Comparison of the proposed classification with current land use}

The CORINE-2012 land cover map was used to compare the current land use with the suitability classes. For calculating land use efficiency, the proposed map and current land use map were superimposed. The polygons of current land use were extracted from the proposed land use map. With this process, it was determined how much of the land is used efficiently.

\section{Results and discussion}

Figure 5 presents the agricultural land suitability map of the study area. In the area, $2.95 \%$ of the lands are highly suitable; $10.37 \%$ are moderately suitable and $53.47 \%$ are marginally suitable for agricultural usage. In the study area, $33.21 \%$ of the lands are not suitable for agriculture (Table 8). Not suitable classes are caused by LUCC and soil depth. While the LUCC changes from I to VIII, particularly depth decreases and slope increases. Other limiting factors affect the decreases in suitability besides LUCC and soil depth. In the study, $67.87 \%$ of the lands are in class VII. The depth was shallow $(20-50 \mathrm{~cm})$ and very shallow $(<20 \mathrm{~cm})$ in 95.8\% of the lands. Similarly, Akınc1 et al. (2013) stated that $51.3 \%$ of the lands in their study area were marginally suitable due to the area being mountainous and sloping conditions. Bandyopadhyay et al. (2009) reported this rate as $70 \%$. Akbulak (2010) stated that $30.8 \%$ of the lands were marginally suitable for agriculture in his research area. 


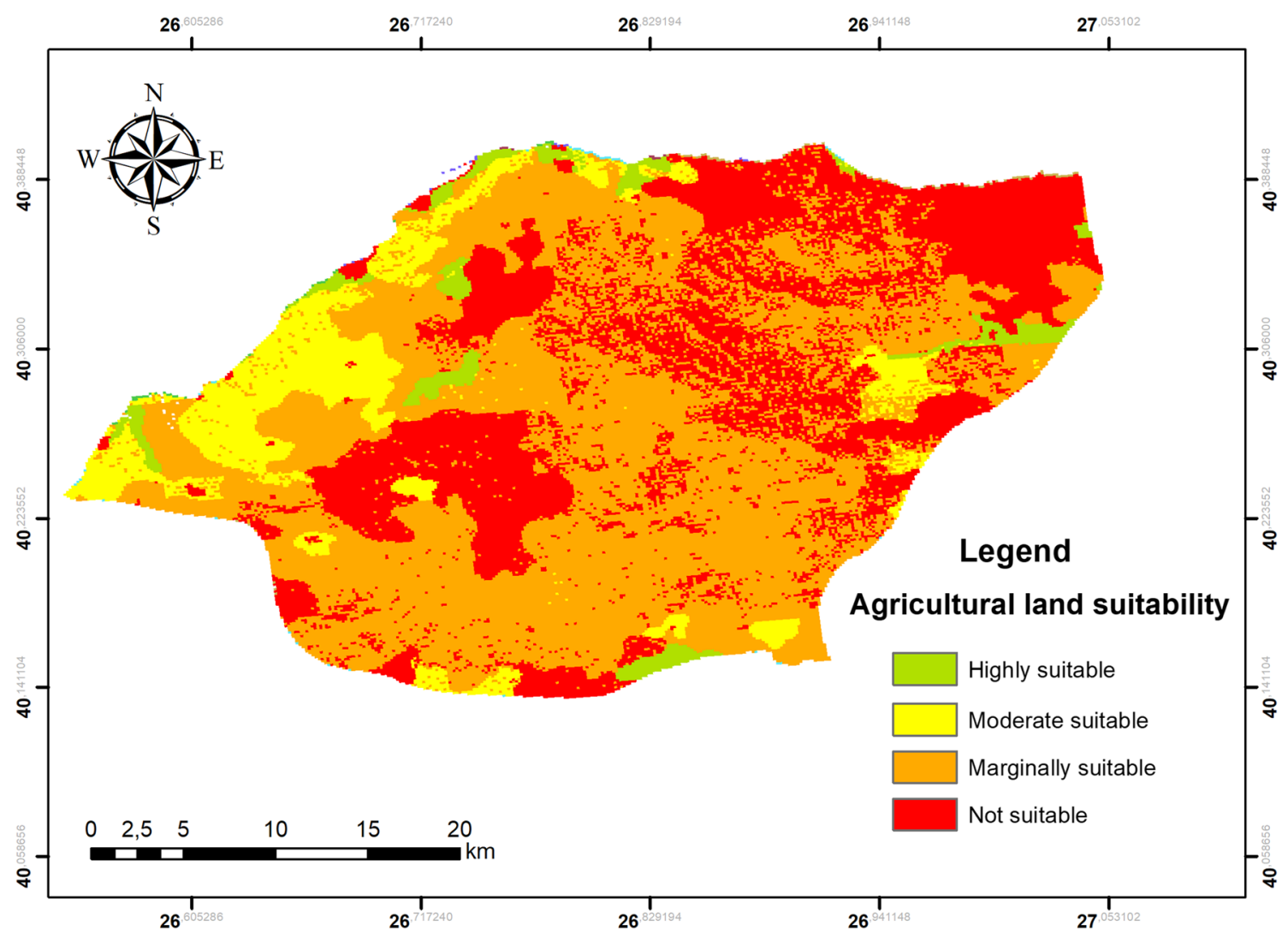

Fig. 5 Land suitability map for agriculture

Table 8 Suitability classification for agricultural purpose

Agricultural land suitability

\begin{tabular}{lrr}
\hline & \multicolumn{1}{c}{ ha } & \multicolumn{1}{c}{$\%$} \\
\hline Highly suitable & 2557 & 2.95 \\
Moderate suitable & 8989 & 10.37 \\
Marginally suitable & 46,336 & 53.47 \\
Not suitable & 28,775 & 33.21 \\
Total & 86,657 & 100.00 \\
\hline
\end{tabular}

Based on the data from the CORINE land cover (Fig. 6), $0.97 \%$ of the lands in the study area are used as artificial surfaces; $40.92 \%$ as agricultural lands, $57.47 \%$ as forests, $0.10 \%$ as wetlands and $0.54 \%$ as water bodies (Table 9). Table 10 presents the comparison of the data obtained from the suitability analysis and the data from the CORINE land cover.

Highly suitable lands for agriculture cover 2557 ha $(2.95 \%)$ of the total land $(86,657$ ha). Of these lands, which are the most suitable lands for agricultural production, $14.12 \%$ are used as artificial surfaces, $69.53 \%$ as agricultural lands, $14.47 \%$ as forests, $0.08 \%$ as wetlands and $1.80 \%$ as water bodies. These lands have the highest potential for agricultural production. The data demonstrated that $14.12 \%$ of the lands are urbanized. Urbanization is the major problem with these lands. Many researchers pointed out that agricultural areas are destroyed due to urbanization (Ricketts and Imhoff 2003; Chen 2007; Everest 2017). Of these areas, $69.53 \%$ are currently used for agricultural purposes. Data show that the majority of the lands are used for proper usage. It is notable that $14.4 \%$ of the highly suitable lands are used as forest. However, VI and VII class lands are recommended for forest, where there is less depth and more slope (MoraArroyo et al. 2005; Barral and Oscar 2012).

The moderately suitable lands cover 8989 ha $(10.37 \%)$ of the total area $(86,657 \mathrm{ha})$. Of these lands, which are moderately suitable for agricultural production, $2.25 \%$ are used as artificial surfaces; $79.07 \%$ as agricultural lands; $17.71 \%$ as forests, $0.23 \%$ as wetlands and $0.73 \%$ as water bodies. The negative impact of urbanization is evident in these lands. However, this effect is less favorable than the highly suitable areas with $79.07 \%$ of the moderately suitable lands used for agricultural purposes. Relative to the highly suitable areas, the moderately suitable areas have less depth and greater slope.

The marginally suitable lands cover 46,336 ha $(53.47 \%)$ of the total land $(86,657 \mathrm{ha})$. It is more difficult to perform agricultural production in marginally suitable lands due to 


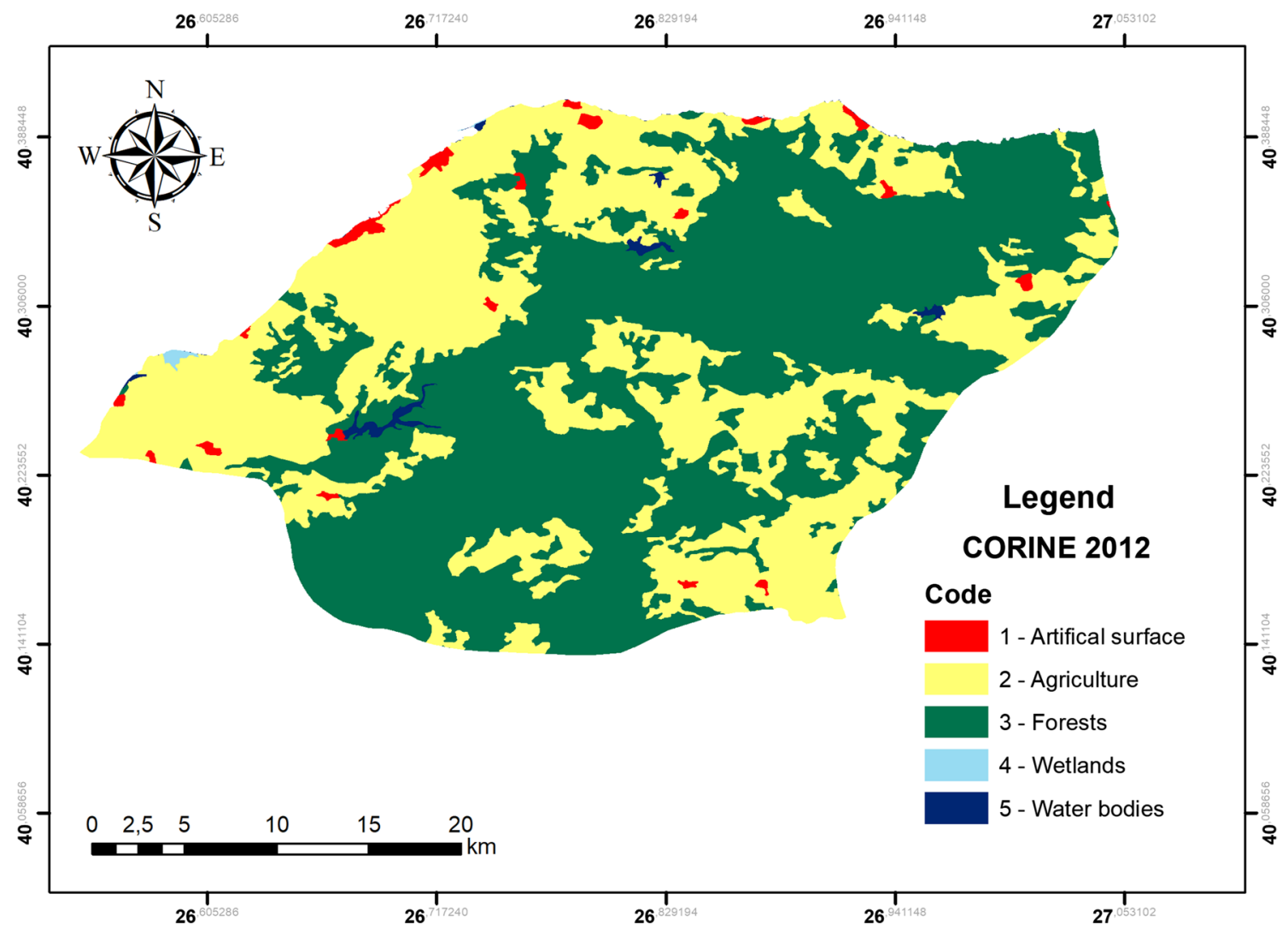

Fig. 6 CORINE 2012 land cover data

Table 9 CORINE land cover of Lapseki

\begin{tabular}{llrl}
\hline Land cover & Code & Ha & $\%$ \\
\hline Artificial surfaces & 1 & 840 & 0.97 \\
Agricultural lands & 2 & 35,463 & 40.92 \\
Forests & 3 & 49,798 & 57.47 \\
Wetlands & 4 & 86 & 0.10 \\
Water bodies & 5 & 470 & 0.54 \\
Total & & 86,657 & 100.00 \\
\hline
\end{tabular}

economic reasons and severe limiting factors of the land. A limited number of plants can be grown in these lands under conservative agriculture conditions (Richards et al. 2014). While $45.71 \%$ of these lands are used for agricultural purposes, $53.60 \%$ of them are forestry. These lands are also located in the higher parts of the study area, which are also problematic in terms of slope and depth. Different studies indicated that marginally suitable lands are generally cultivated (Akbulak 2010; Cengiz et al. 2013; Akınc1 et al. 2013).
Table 10 Comparison of the agricultural land suitability with the CORINE land cover

\begin{tabular}{|c|c|c|c|c|c|c|c|c|c|c|c|c|}
\hline \multirow[t]{4}{*}{ Suitability } & \multicolumn{10}{|c|}{ Comparison the suitability with the CORINE 2012 land cover } & \multirow{2}{*}{\multicolumn{2}{|c|}{$\begin{array}{l}\text { Proposed classi- } \\
\text { fication results }\end{array}$}} \\
\hline & \multirow{2}{*}{\multicolumn{2}{|c|}{$\begin{array}{l}\text { Artificial } \\
\text { surfaces }\end{array}$}} & \multirow{2}{*}{\multicolumn{2}{|c|}{$\begin{array}{l}\text { Agricultural } \\
\text { lands } \\
\text { Area }\end{array}$}} & \multirow{2}{*}{\multicolumn{2}{|c|}{$\begin{array}{l}\text { Forests } \\
\text { Area }\end{array}$}} & \multirow{2}{*}{\multicolumn{2}{|c|}{$\begin{array}{l}\text { Wet- } \\
\text { lands }\end{array}$}} & \multirow{2}{*}{\multicolumn{2}{|c|}{$\begin{array}{l}\text { Water } \\
\text { bodies }\end{array}$}} & & \\
\hline & & & & & & & & & & & \multirow[b]{2}{*}{ ha } & \multirow[b]{2}{*}{$\%$} \\
\hline & ha & $\%$ & ha & $\%$ & ha & $\%$ & ha & $\%$ & ha & $\%$ & & \\
\hline Highly suitable & 361 & 14.12 & 1778 & 69.53 & 370 & 14.47 & 2 & 0.08 & 46 & 1.80 & 2557 & 100.00 \\
\hline Moderate suitable & 202 & 2.25 & 7108 & 79.07 & 1592 & 17.71 & 21 & 0.23 & 66 & 0.73 & 8989 & 100.00 \\
\hline Marginally suitable & 170 & 0.36 & 21,180 & 45.71 & 24,837 & 53.60 & 55 & 0.12 & 94 & 0.20 & 46,336 & 100.00 \\
\hline Not suitable & 107 & 0.37 & 5397 & 18.76 & 22,999 & 79.93 & 8 & 0.03 & 264 & 0.92 & 28,775 & 100.00 \\
\hline Total (ha) & 840 & & 35,463 & & 49,798 & & 86 & & 470 & & 86,657 & \\
\hline
\end{tabular}


The study concluded that the lands not suitable for agricultural covered 28,775 ha $(33.21 \%)$ of the total area. These lands, which are not suitable for agriculture, are sloping, shallow-very shallow, high lands with erosion threats and have too many soil limiting factors. Of these lands, $18.76 \%$ are used for agricultural purposes. Performing agricultural production on these lands will cause a decrease in yield and soil loss due to erosion. Cultural processes such as soil cultivation, irrigation and fertilization are not economically feasible in these areas. It is essential to perform conservative and sustainable agricultural practices in these areas. Of these lands, $79.93 \%$ are used as forests and this is an accepted land use for these areas.

In the literature, there are many studies about agricultural land suitability (Mokarram and Aminzadeh 2010; Kuria et al. 2011; Mesgaran et al. 2017). In these studies, research mainly focus on determining suitable sites for agricultural use. The suitability of agricultural land was determined in this study. In addition to land evaluation study, land use efficiency analysis was performed by comparing with the current land use data. After comparison, valuable data were produced that can be presented to land owners and decision makers about how to use or plan the land. Similarly, Zolekar (2018) studied the agricultural land suitability in a hilly zone. The researcher used the error matrix to determine the accuracy and examined the relationship between output data and true data with accuracy assessments. In this paper, accuracy was measured by using CORINE land cover data. These outputs show that there is a tendency in new studies to test the compliance with the suitability classes in the land.

Similarly, Ennaji et al. (2018) determined agricultural land suitability based on some soil characteristics and slope conditions and they produced a sustainable agricultural support plan for their study area. Kazemi and Akinci (2018) determined agricultural land suitability and suggested suitable sites for rainfed agriculture. Barakat et al. (2017) investigated land suitability for agriculture and they determined intensive agricultural areas in their study area. $\mathrm{Li}$ et al. (2017) examined land suitability for marginal agricultural lands and presented a sustainable land use plan for these marginal areas. Recent studies in the literature used GIS and AHP techniques, like this study. The researchers tried to find solutions to problems in their study area. In this study, practical work was carried out by using basic soil maps, topographic data, GIS and AHP. With this study, agricultural land suitability was determined for Lapseki. The originality and importance of this study is that the study was carried out in a special location, which has branded products. Sharma et al. (2018) stated there are important research teams who study GIS applications in agriculture. Nevertheless, there is relatively less focus on land suitability and site selection studies, knowledge-based systems, natural resource allocation and impact assessment applications. In addition, this idea is supported by many researchers (Wachowiak et al. 2017; Zolekar 2018; Dedeoğlu and Dengiz 2019; Habibie et al. 2019; Tercan and Dereli 2020). Therefore, the information produced by this study also contributes to the literature. Considering the recent COVID-19 pandemic, the value of agriculture and natural resources has increased even more (Siche 2020; Hobbs 2020; Kerr 2020; Poudel et al. 2020). It has become a more important issue during the COVID-19 pandemic that the land with special agricultural potential be used in accordance with the potential for sustainable use. Food security and safety are now a global concern. Determining the suitability of agricultural lands, revealing their potential, and producing rational and sustainable plans can resolve these concerns. When these evaluation studies and plans are not performed, degradation, environmental problems and food production problems are experienced. The results of this study will guide users and decision makers, and the results of the study can be implemented rather than being archive data. The use of the data produced by study will also contribute to the economy. Sharma et al. (2018) stated that land suitability assessment plays an important role in gathering information for decision makers about opportunities and limiting characteristics of an area.

\section{Conclusion}

This study determined the agricultural land suitability by using basic soil properties, DEM data, GIS and AHP methods. A total of seven parameters were used to determine the suitability of lands for agriculture, and the findings were reclassified based on FAO (1977). As a result of matrix calculations performed in AHP, LUCC 0.371 was found to be the most effective factor and elevation 0.021 was found to be the least effective factor. Obtaining different weight values with AHP was interpreted as a benefit in terms of this study. The study concluded that $66.79 \%$ of the lands are suitable for agricultural usage to varying degrees. The highly suitable lands covered only $2.95 \%$ of the study area. These lands should only be used for agricultural purposes, but the greatest problem in these lands is urbanization. The marginally suitable lands for agriculture are extensively used as agricultural and forests with $45.71 \%$ of the marginally suitable lands used as agricultural lands. Farmers and relevant institutions should pay more attention to these lands. Improper use of land will increase erosion in these areas. In the study, $15 \%$ of the not suitable land is used for agricultural practice. It would not be an economically wise decision to perform agricultural production in these lands due to improper management techniques causing erosion. Fruit orchards are widespread in the areas both marginally suitable and not suitable for agriculture. In these lands, agricultural activities should continue by applying conservative agricultural 
principles such as terracing. The lands, which are not suitable for agricultural usage, are more suitable for use as forests. About $80 \%$ of these lands are under forest cover. It is notable that class VII lands cover $67.87 \%$ of the study area. These lands, which have slope and depth problems, greatly restrict the areas suitable for agricultural production.

This study once again demonstrated that AHP is a very powerful multiple-criteria decision-making method. The use of AHP methodology and GIS techniques was very useful for the determination of land suitability in this study. AHP provides different insights into the land evaluation process as well. While all criteria are considered equal in different land evaluation methods, different weight values are given in AHP. Expert opinions and recommendations are of vital importance during the step of assigning weights. The results of this study will be useful for decision makers in making planning and production policies and in determining product support and marketing strategies.

Acknowledgements The authors are indebted to the anonymous reviewers and the editors for their valuable and constructive suggestions. In this study, there are no funding information and organization.

\section{Compliance with ethical standards}

Conflict of interest The authors declare that they have no conflict of interest.

\section{References}

ADNKS (2017) Address-based population registration system. Population statistics. https://adres.nvi.gov.tr/Home. Accessed 26 June 2018

Akbulak C (2010) Analitik hiyerarşi süreci ve coğrafi bilgi sistemleri ile Yukarı Kara Menderes Havzası'nın arazi kullanımı uygunluk analizi. Uluslararası İnsan Bilimleri Dergisi 7(2):557-576

Akıncı H, Özalp AY, Turgut B (2013) Agricultural land use suitability analysis using GIS and AHP technique. Comput Electron Agric 97:71-82

Al-Shalabi MA, Mansor SB, Ahmed NB, Shiriff R (2006) GIS based multicriteria approaches to housing site suitability assessment. In: XXIII FIG congress, October 8-13, Germany

Altınbaş Ü (2006) Toprak etüd ve haritalama. Ege Üniversitesi Basımevi, Bornova

Al-Yahyai S, Charabi Y, Gastli A, Al-Badi A (2012) Wind farm land suitability indexing using multi-criteria analysis. Renew Energy 44:80-87

Asakereh A, Soleymani M, Sheikhdavoodi MJ (2017) A GIS-based fuzzy-AHP method for the evaluation of solar farms locations: case study in Khuzestan province, Iran. Sol Energy 155:342-353

Ashraf MI, Zhao Z, Bourque CPA, Meng FR (2012) GIS-evaluation of two slope-calculation methods regarding their suitability in slope analysis using high-precision LiDAR digital elevation models. Hydrol Process 26(8):1119-1133

Bale CL, Williams JB, Charley JL (1998) The impact of aspect on forest structure and floristics in some Eastern Australian sites. For Ecol Manag 110(1-3):363-377
Bandyopadhyay S, Jaiswal RK, Hegde VS, Jayaraman V (2009) Assessment of land suitability potentials for agriculture using a remote sensing and GIS based approach. Int J Remote Sens 30(4):879-895

Barakat A, Ennaji W, El Jazouli A, Amediaz R, Touhami F (2017) Multivariate analysis and GIS-based soil suitability diagnosis for sustainable intensive agriculture in Beni-Moussa irrigated subperimeter (Tadla plain, Morocco). Model Earth Syst Environ 3(1):3

Barral MP, Oscar MN (2012) Land-use planning based on ecosystem service assessment: a case study in the Southeast Pampas of Argentina. Agr Ecosyst Environ 154:34-43

Bojorquez-Tapia LA, Diaz-Mondragon S, Ezcurra E (2000) GISbased approach for participatory decision making and land suitability assessment. Int J Geogr Inf Sci 15(2):129-151

Brans JP, Vincke P (1985) Note-a preference ranking organisation method: (the PROMETHEE method for multiple criteria decision-making). Manag Sci 31:647-656

Burrough PA, McDonnell RA (1998) Creating continuous surfaces from point data. In: Principles of geographic information systems. Oxford University Press, Oxford

Cengiz T, Akbulak C (2009) Application of analytical hierarchy process and geographic information systems in land-use suitability evaluation: a case study of Dümrek village (Çanakkale, Turkey). Int J Sustain Dev World Ecol 16(4):286-294

Cengiz T, Akbulak C, Özcan H, Baytekin H (2013) Gökçeada'da optimal arazi kullanımının belirlenmesi. Tarım Bilimleri Dergisi 19:148-162

Chandio IA, Matori AN, Yusof K, Talpur MH, Aminu M (2014) GIS-based land suitability analysis of sustainable hillside development. Procedia Eng 77:87-94

Chen CT (2000) Extensions of the TOPSIS for group decisionmaking under fuzzy environment. Fuzzy Sets Syst 114(1):1-9

Chen J (2007) Rapid urbanization in China: a real challenge to soil protection and food security. CATENA 69(1):1-15

Chen Y, Khan S, Paydar Z (2010) To retire or expand? A fuzzy GISbased spatial multi-criteria evaluation framework for irrigated agriculture. Irrig Drain 59(2):174-188

CLC-Corine Land Cover (2012) European Environment Agency. www.eea.europa.eu

Collins MG, Steiner FR, Rushman MJ (2001) Land-use suitability analysis in the United States: historical development and promising technological achievements. Environ Manag 28(5):611-621

Dedeoğlu M, Dengiz O (2019) Generating of land suitability index for wheat with hybrid system aproach using AHP and GIS. Comput Electron Agric 167:105062

Dezert J, Tacnet JM, Batton-Hubert M. Smarandache F (2010) Multicriteria decision making based on DSmT-AHP. In BELIEF: workshop on the theory of belief functions. Belief Functions and Applications Society (BFAS)

Dinç U, Şenol S (1997) Toprak etüd ve haritalama. ÇÜ Ziraat Fakültesi Genel Yayın (161)

Driessen PM, Konijn NT (1992) Land-use systems analysis. WAU and Interdisciplinary Research (INRES)

Dunn M, Hickey R (1998) The effect of slope algorithms on slope estimates within a GIS. Cartography 27(1):9-15

Elaalem M, Comber A, Fisher P (2011) A comparison of fuzzy AHP and ideal point methods for evaluating land suitability. Trans GIS 15(3):329-346

Ennaji W, Barakat A, El Baghdadi M, Oumenskou H, Aadraoui M, Karroum LA, Hilali A (2018) GIS-based multi-criteria land suitability analysis for sustainable agriculture in the northeast area of Tadla plain (Morocco). J Earth Syst Sci 127(6):79

Everest T (2017) Assessment of land use efficiency in Ezine district of Çanakkale. Turk J Argic Res 4(2):109-123 
Everest T, Akbulak C, Özcan H (2011) Arazi kullanım etkinliğinin değerlendirilmesi: Edirne ili Havsa ilçesi örneği. Anadolu Tarım Bilimleri Dergisi 26(3):251-257

FAO (1977) A framework for land evaluation. Int Inst Land Reclam Improv 22:87

FAO (1989) Guidelines for land use planning. Interdepartmental working group on land planning. FAO, Rome

Feizizadeh B, Blaschke T (2013) Land suitability analysis for Tabriz County, Iran: a multi-criteria evaluation approach using GIS. J Environ Plan Manag 56(1):1-23

Gabet EJ, Mudd SM (2009) A theoretical model coupling chemical weathering rates with denudation rates. Geology 37(2):151-154

Goulden T, Hopkinson C, Jamieson R, Sterling S (2016) Sensitivity of DEM, slope, aspect and watershed attributes to LiDAR measurement uncertainty. Remote Sens Environ 179:23-35

Habibie MI, Noguchi R, Shusuke M, Ahamed T (2019) Land suitability analysis for maize production in Indonesia using satellite remote sensing and GIS-based multicriteria decision support system. GeoJournal 1-31

Hashemizadeh A, Ju Y, Dong P (2019) A combined geographical information system and best-worst method approach for site selection for photovoltaic power plant projects. Int J Environ Sci Technol $1-16$

Hobbs JE (2020) Food supply chains during the COVID-19 pandemic. Can J Agric Econ/Revue canadienne d'agroeconomie

Horn BK (1981) Hill shading and the reflectance map. Proc IEEE 69(1):14-47

Kapluhan E (2013) Türkiye'de Kuraklık ve Kuraklığın Tarıma Etkisi. Marmara Coğrafya Dergisi 27:487-510

Kazemi H, Akinci H (2018) A land use suitability model for rainfed farming by multi-criteria decision-making analysis (MCDA) and geographic information system (GIS). Ecol Eng 116:1-6

Kerr WA (2020) The COVID-19 pandemic and agriculture: short- and long-run implications for international trade relations. Can J Agr Econ. https://doi.org/10.1111/cjag.12230

KHGM (1999) T. C. Prime Ministry Services of the General Directorate of Village Services, provincial report (Çanakkale) no: 17, Ankara

Kinnell PIA (2000) The effect of slope length on sediment concentrations associated with side-slope erosion. Soil Sci Soc Am J 64(3):1004-1008

Kuria D, Ngari D, Waithaka E (2011) Using geographic information systems (GIS) to determine land suitability for rice crop growing in the Tana delta. J Geogr Reg Plan 4(9):525-532

Li G, Messina JP, Peter BG, Snapp SS (2017) Mapping land suitability for agriculture in Malawi. Land Degrad Dev 28(7):2001-2016

Maddahi Z, Jalalian A, Zarkesh MMK, Honarjo N (2017) Land suitability analysis for rice cultivation using a GIS-based fuzzy multicriteria decision making approach: central part of Amol district, Iran. Soil Water Res 12:29-38

Malckzewski J, Ogryczak W (1995) The multiple criteria location problem: 1. A generalized network model and the set of efficient solutions. Environ Plan 27:1931-1960

Malczewski J (2004) GIS-based land-use suitability analysis: a critical overview. Prog Plan 62(1):3-65

Mesgaran MB, Madani K, Hashemi H, Azadi P (2017) Iran's land suitability for agriculture. Sci Rep 7(1):7670

Meyer MD, North MP, Gray AN, Zald HS (2007) Influence of soil thickness on stand characteristics in a Sierra Nevada mixed-conifer forest. Plant Soil 294(1-2):113-123

Mohammadizadeh MJ, Karbassi AR, Nabi Bidhendi GR, Abbaspour M (2016) Integrated environmental management model of air pollution control by hybrid model of DPSIR and FAHP. Glob J Environ Sci Manag 2(4):381-388

Mokarram M, Aminzadeh F (2010) GIS-based multicriteria land suitability evaluation using ordered weight averaging with fuzzy quantifier: a case study in Shavur Plain, Iran. Int Arch Photogramm Remote Sens Spat Inf Sci 38(2):508-512

Mokarram M, Mirsoleimani A (2018) Using fuzzy-AHP and order weight average (OWA) methods for land suitability determination for citrus cultivation in ArcGIS (case study: Fars province Iran). Phys A Stat Mech Appl 508:506-518

Montgomery DR (2007) Soil erosion and agricultural sustainability. Proc Natl Acad Sci 104(33):13268-13272

Mora-Arroyo JP, Sánchez-Azofeifa GA, Rivard B, Calvo JC, Janzen DH (2005) Dynamics in landscape structure and composition for the Chorotega region, Costa Rica from 1960 to 2000. Agric Ecosyst Environ 106(1):27-39

MTA (2018) General directorate of mineral research and exploration. Geology of Turkey. http://yerbilimleri.mta.gov.tr/anasayfa.aspx. Accessed 30 June 2018

Mustafa AA, Singh M, Sahoo RN, Ahmed N, Khanna M, Sarangi A, Mishra AK (2011) Land suitability analysis for different crops: a multi criteria decision making approach using remote sensing and GIS. Researcher 3(12):61-84

Özcan H (2015) Storie index ve arazi derecelendirme sistemi. Toprak etüt ve haritalama el kitabı. Gıda, Tarım ve Hayvancılık Bakanlığı, Tarım Reformu Genel Müdürlüğü, pp 509-547

Özcan T, Çelebi N, Esnaf Ş (2011) Comparative analysis of multicriteria decision making methodologies and implementation of a warehouse location selection problem. Expert Syst Appl 38(8):9773-9779

Özcan H, Aydemir S, Çullu MA, Günal H, Eren M, Kadir S, Ekinci H, Everest T, Sungur A, FitzPatrick EA (2018) Vertisols. In: The soils of Turkey. Springer, Cham, pp 169-206

Ozdemir MS, Saaty TL (2006) The unknown in decision making: what to do about it. Eur J Oper Res 174(1):349-359

Özkan K, Kantarci MD (2008) Beysehir golu havzasi'nin orman yetisme ortami alt bolgeleri ve yoreleri gruplari. Fac For J 2:123-135

Özyazıcı MA, Dengiz O, Sağlam M, Turan ID (2016) Determination of land suitability site for some forage legumes using multi-criteria assessment and geostatistical approach. PONTE Int Sci Res J 72:3

Parlak M (2012) Determination of soil erosion over different land uses by mini rainfall simulator. J Food Agric Environ 10(3-4):929-933

Parry JA, Ganaie SA, Bhat MS (2018) GIS based land suitability analysis using AHP model for urban services planning in Srinagar and Jammu urban centers of J\&K, India. J Urban Manag 7:46-56

Pimentel D, Harvey C, Resosudarmo P, Sinclair K, Kurz D, McNair M, Blair R (1995) Environmental and economic costs of soil erosion and conservation benefits. Science 267(5201):1117-1123

Poudel PB, Poudel MR, Gautam A, Phuyal S, Tiwari CK, Bashyal N, Bashyal S (2020) COVID-19 and its global impact on food and agriculture. J Biol Today's World 9(5):221

PRB (2018) Population Reference Bureau (PRB). https://www.prb. org/2018-world-population-data-sheet-with-focus-on-changingage-structures/

Qiu L, Zhu J, Pan Y, Hu W, Amable GS (2017) Multi-criteria land use suitability analysis for livestock development planning in Hangzhou metropolitan area, China. J Clean Prod 161:1011-1019

Richards BK, Stoof CR, Cary IJ, Woodbury PB (2014) Reporting on marginal lands for bioenergy feedstock production: a modest proposal. BioEnergy Res 7(3):1060-1062

Ricketts T, Imhoff M (2003) Biodiversity, urban areas, and agriculture: locating priority ecoregions for conservation. Conserv Ecol 8(2):1

Saaty TL (1980) The analytic hierarchy process: planning, priority setting, resources allocation. McGraw, New York, p 281

Selby MJ (1976) Slope erosion due to extreme rainfall: a case study from New Zealand. Geogr Ann Ser A Phys Geogr 58(3):131-138

Sharma R, Kamble SS, Gunasekaran A (2018) Big GIS analytics framework for agriculture supply chains: a literature review identifying the current trends and future perspectives. Comput Electron Agric 155:103-120 
Siche R (2020) What is the impact of COVID-19 disease on agriculture? Sci Agropecu 11(1):3-6

Steinitz C (1976) Hand-drawn overlays: their history and prospective uses. Landsc Archit 66:444-455

Tercan E, Dereli MA (2020) Development of a land suitability model for citrus cultivation using GIS and multi-criteria assessment techniques in Antalya province of Turkey. Ecol Ind 117:106549

Thornthwaite CW (1948) An approach to a rational classification of climate. Geogr Rev 38:55-94

Travis MR, Elsner GH, Iverson WD, Johnson CG (1975) VIEWIT computation of seen areas, slope, and aspect for land use planning. Gen. Tech. Rep. PSW-GTR-11. Pacific Southwest Research Station, Forest Service, US Department of Agriculture, Berkeley, CA

Tzeng GH, Huang JJ (2011) Multiple attribute decision making: methods and applications. Chapman and Hall/CRC, London

Wachowiak MP, Walters DF, Kovacs JM, Wachowiak-Smolíková R, James AL (2017) Visual analytics and remote sensing imagery to support community-based research for precision agriculture in emerging areas. Comput Electron Agric 143:149-164
WRB (2014) World reference base for soil resources 2014 international soil classification system for naming soils and creating legends for soil maps. FAO, Rome

Yimer F, Ledin S, Abdelkadir A (2006) Soil property variations in relation to topographic aspect and vegetation community in the southeastern highlands of Ethiopia. For Ecol Manag 232(1-3):90-99

Zevenbergen LW, Thorne CR (1987) Quantitative analysis of land surface topography. Earth Surf Proc Land 12(1):47-56

Zhang J, Su Y, Wu J, Liang H (2015) GIS based land suitability assessment for tobacco production using AHP and fuzzy set in Shandong province of China. Comput Electron Agric 114:202-211

Zolekar RB (2018) Integrative approach of RS and GIS in characterization of land suitability for agriculture: a case study of Darna catchment. Arab J Geosci 11(24):780

Zolekar RB, Bhagat VS (2015) Multi-criteria land suitability analysis for agriculture in hilly zone: remote sensing and GIS approach. Comput Electron Agric 118:300-321 